\title{
Considering African art today: the case of the installation "La bouche du roi"
}

\section{Pensando sobre a arte africana de hoje: o caso da instalação "La bouche du roi"}

\author{
Walace Rodrigues \\ Doutor em Humanidades pela Universiteit Leiden (Holanda). Professor da Universidade Federal do Tocantins (UFT) - \\ walace@uft.edu.br \\ Michol Malia Miller \\ Mestranda em Ensino de Língua e Literatura pela Universidade Federal do Tocantins (UFT) - \\ michol.m.miller@gmail.com \\ Valéria da Silva Medeiros \\ Doutora em Estudos da Literatura pela Pontifícia Universidade Católica do Rio de Janeiro (PUC-RIO). Professora da \\ Universidade Federal do Tocantins (UFT) - medeiros.vs@hotmail.com
}

\begin{abstract}
This paper seeks to consider some specific aspects of contemporary art, specifically contemporary African art, through an examination of the installation "La bouche du roi" by Romuald Hazoumé of the Republic of Benin. It presents a qualitative analysis of this significant work of art and its aesthetic and critical particularities, through the use of bibliographic references that dialogue with the area of art. The results of this paper show that artwork today is not restricted to more developed countries, but also includes developing countries, thus revealing unique aesthetic-socio-cultural facets of, and thus enriching thoughts about, contemporary art today.
\end{abstract}

Palavras-chave: Contemporary arts. African arts. Visual arts. "La bouche du roi".

\begin{abstract}
Resumo
Este artigo tem como objetivo pensar especificidades da arte contemporânea, principalmente da arte africana atual, através da instalação "La bouche du roi" (A boca do rei, em tradução livre), de Romuald Hazoumé, da República do Benin. Apresenta-se uma análise qualitativa da obra e de suas particularidades estéticas e críticas por meio de uma bibliografia que dialoga com a área de artes. Os resultados mostram que a arte atual não se restringe aos países mais desenvolvidos, mas também aos países em desenvolvimento, revelando facetas estético-sócio-culturais únicas e enriquecedoras para pensar a arte de hoje.
\end{abstract}

Keywords: Arte contemporânea. Arte africana. Artes visuais. "La bouche du roi".

Recebido em: 23/07/2018

Aceito em: 29/10/2018 


\section{INTRODUCTION}

Nowadays, contemporary African artwork has been present in many exhibitions around the world. The importance given to these works and the messages they convey are of great importance to expanding our understanding of the conditions related to the production of art in Africa, exemplifying the experience of the creation of culture in the developing world.

As an example of the aesthetics of developing countries in the tropics, Brazilian filmmaker Glauber Rocha created the concept of "aesthetics of hunger"1 (SCHWARZ, 1992, p. 72) to designate the use of precarious means and second-hand materials (in the developing Brazil of the 1960s) in the creation of cultural artefacts, such as films or works in the fine arts. Rocha sought to create a new understanding of the aesthetics of art produced in a developing country, especially with respect to the material difficulties, as well as the aesthetic possibilities involved in this process. $A$ similar approach to the "aesthetics of hunger" can be observed in current works by artist Romuald Hazoumé, from the Republic of Bénin, West Africa.

With this in mind, we take this specific work of art as an example of art produced in developing countries, outside of the Europe-USA circles of artistic production. This specific installation invites viewers to consider the ways in which art is universal and how it can speak to us all.

We cannot forget that conceptions of art for native Africans (non-Western peoples) differ from that of Europeans. The latter is based on the Greek concepts of beauty, proportion, balance and harmony of forms. Even nowadays these concepts can be observed in Western artworks. On the other hand, the non-Western arts show more direct dialogues with reality, with oral tradition and with the people's things.

\section{SPECIFICITIES OF THE ARTWORK “LA BOUCHE DU ROI” AND SOME THOUGHTS}

As a way of prefacing our brief explanation about the importance of African art and the discourses derived from them today, we present a definition of the value of art in postmodern times, provided by philosopher Homi Bhabha. His definition can be applied to any work of art

1 As Brazilians, the country with the second largest black population in the world, just after Nigeria, we take the liberty of using Brazilian concepts in this essay. We characterize both Brazil and Bénin as developing countries, understanding that there are various differences between them but including them both as in the periphery of captalistic production. Although nowadays Brazil is considered an industrialized country, this was not the case in the 1960s. 
produced by Hazoumé and many other artists around the world, and the following exercpt will help us to better understand this paper:

\begin{abstract}
The value of art lies not in its transcendent reach but in its translation capacity: in the possibility of moving between media, materials, and genres, each time both marking and remaking the material borders of difference; articulating 'sites' where the question of 'specificity' is ambivalent and complexly construed (BHABHA, 2003, p. 439).
\end{abstract}

This ambivalence and complexity inherent in the specific aspects of a piece of art can be clearly seen in contemporary artwork. In the last decades, contemporary African works of art have been shown in various museums around the world. One can understand them as a clear consequence of the so-called process of globalization.

Artists from the African continent, such Hazoumé, show how the "second-hand" materials found in the developing nations are, more than ever, a remainder of the cruel effects of capitalism on the people who do not own the means of production. The works of Hazoumé deal with, among other issues, the remembrance of the slave trade, the "artesian" commerce of gasoline from Nigeria into Bénin by bike riders, the relationships between the creation of African art today and in the past, the circumstances of daily life in Bénin, and various other situations with important implications for the production of art in Africa.

One of the best examples of Hazoumé's artistic work is the installation piece named "La bouche du roi" (which can be translated as "The Mouth of the King", see image 1), bought by the British Museum in a very intelligent move to commemorate the $200^{\text {th }}$ anniversary of the abolition of the slave trade in the United Kingdom. It is, in our view, one of the most important pieces by a contemporary black African artist found in a European museum.

Firstly, it is necessary to clarify a principal aspect of this work of art: it is related directly to the prints of the slave trade ships by Thomas Clarkson, showing the arrangements of the slaves in the space of these ships. Under the regulated British slave trade, black slaves had to travel to the Americas in these ships, and one of them was the "Brookes". 
Image 1 - "La bouche du roi", by Romuald Hazoumé.

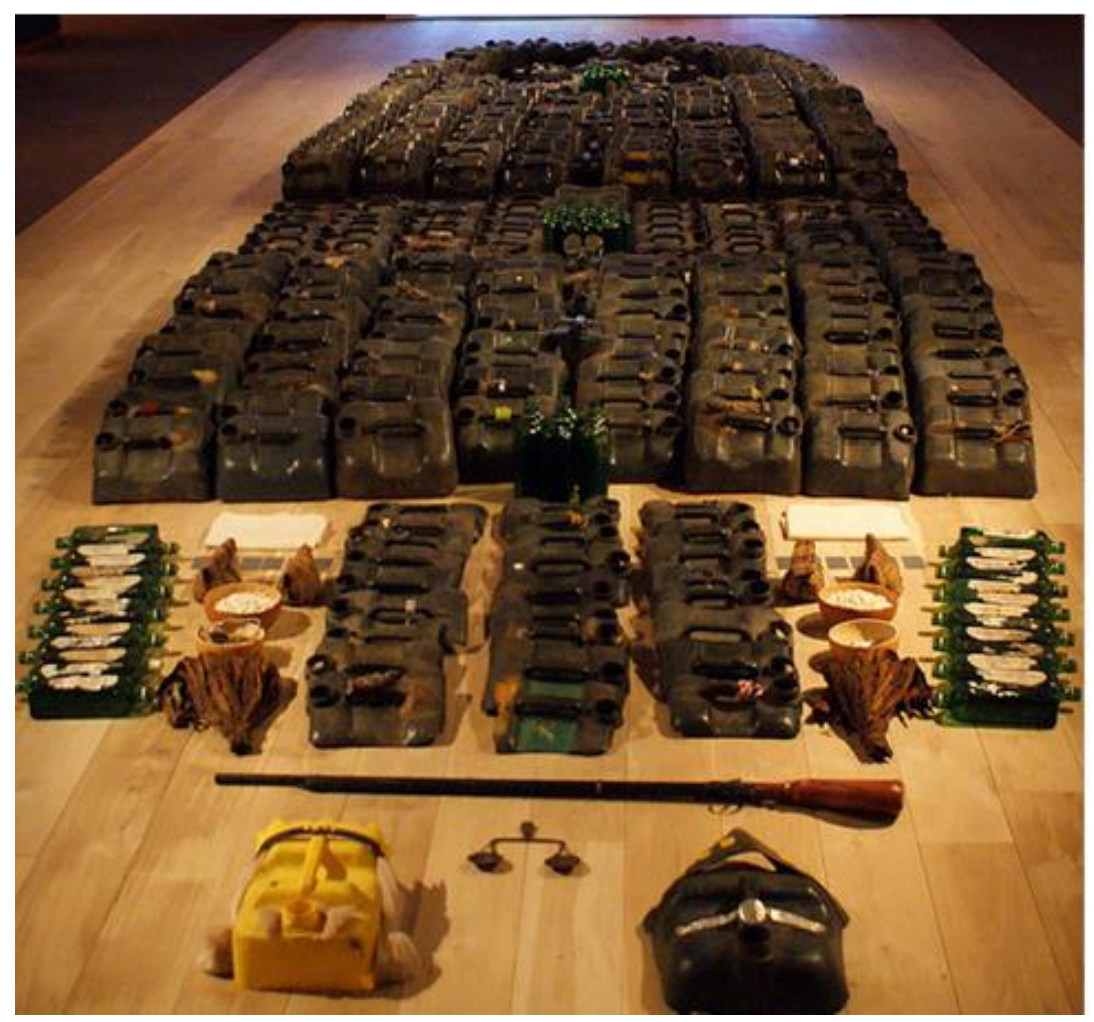

Font: Photo by DaffyDuke, from www.flickr.com

Image 2 - Detail of "Plan section of a slave ship", 1808, by Thomas Clarkson.

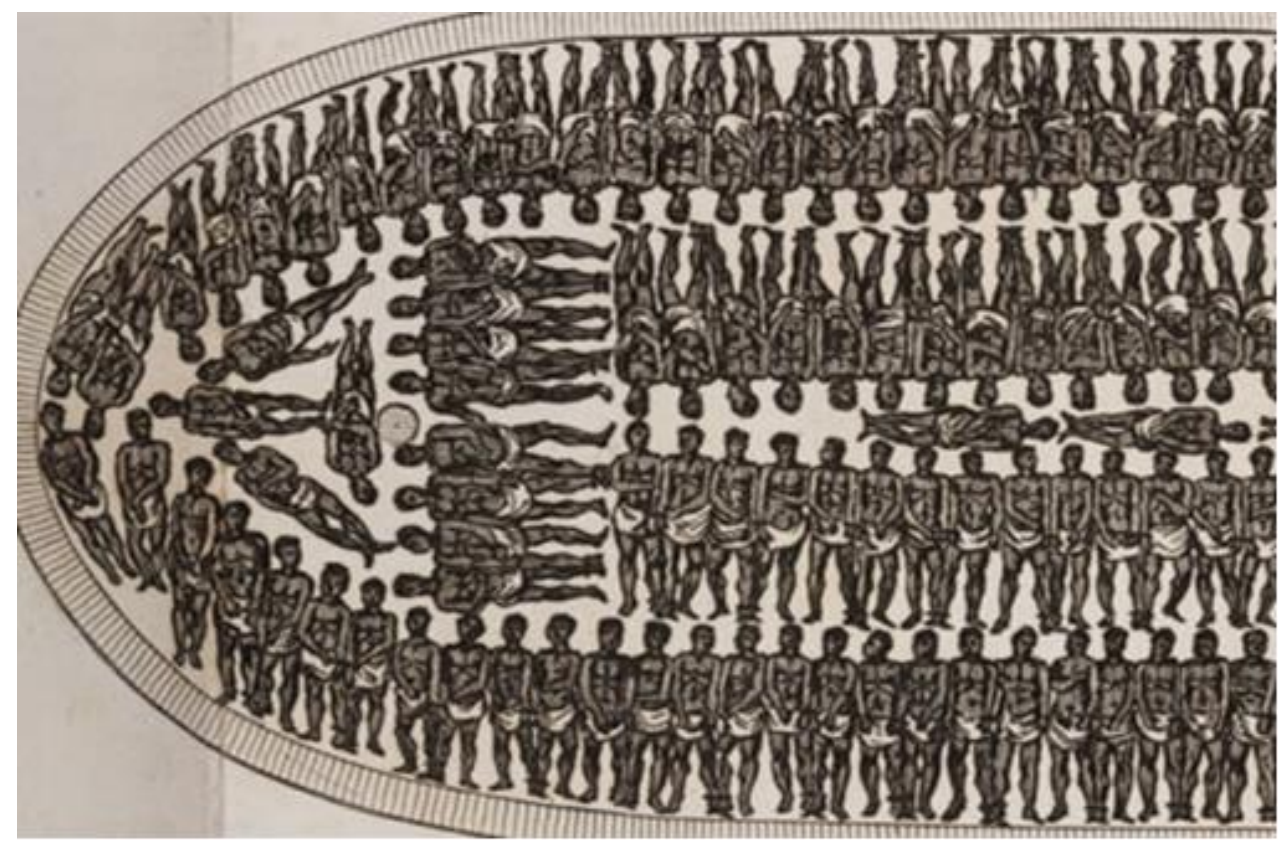

From: https://www.gettyimages.com/detail/news-photo/plan-of-the-interior-of-a-slave-ship-1808-a-plan-of-a-slavenews-photo/463989653\#plan-of-the-interior-of-a-slave-ship-1808-a-plan-of-a-slave-ship-by-picture-id463989653 
These images (see image 2) were produced in 1789 and first published in 1791. The prints are not only a precious piece of history kept in the British Museum, but also a reminder of the cruelty and inhumanity of colonial times. They are a tangible memory of slavery, documented on paper. Thus, it was with these prints in mind that Hazoumé created his artwork entitled "La bouche du roi".

"La bouche du roi" shows, mostly, masks ${ }^{2}$ made from the top part of plastic petrol containers and arranged on the floor, reinterpreting the same formation found in the prints by Clarkson. Each mask represents a slave, and the inclusion of these masks in the work is a direct reference to the current oil trade and exploitation of African countries, in addition to the consequences of these activities for the African population, such as environmental disasters. As the artist cuts the top of the containers and alters them to resemble masks, black masks, they become a person, the black face of a slave from the past, or perhaps an African villager today. Each mask represents either someone from the past who was transported from Africa to the Americas as a slave, or someone in the present whose water supply has been polluted by the oil industry.

Secondly, this work goes beyond the borders of Postcolonial theory, as "La bouche du roi" speaks loudly for itself and inspires reflections from its viewers about all the issues the work invokes: material, social, economic, cultural and many others. Hazoumé deconstructs Clarkson`s print and then pieces it together again in an entirely different way. Furthermore, it is not a 'beautiful'3 ${ }^{3}$ work; on the contrary, there is sense of transgressive joy in its appreciation. It demands questioning and thinking from the spectator. It requires action: a change in behaviour and thinking.

As a work of art produced in a developing country, "La bouche du roi" addresses the economic realities of the use of plastic containers, such that what in rich countries would be considered "trash" is utilized as artistic material. In this sense, Hazoumé uses the same mechanism

\footnotetext{
2 We can not forget the long tradition of mask making in Africa, which spans from the masks of the past, carved in wood, to the ones of today, made out of plastic containers.

3 What we mean by "it is not a 'beautiful' work" is that it does not give the same type of pleasure to the viewer as the Mona Lisa by Leonardo da Vinci, for example. But if we consider the various meanings of beauty in the pancultural XXI century, there are some who would say this is a "beautiful" work. A good passage to describe "La bouche du roi" is one by Ivan Gaskell, when dealing with the concept of beauty in the work of Joseph Beuys: "Such art is not about the skilled fabrication of beautiful things: it has more to do with addressing problems and changing human behaviour. Under its terms the pleasure afforded by the beautiful is at best regarded equivocally" (GASKELL, 2003: p. 273). As well, it is important to point out that we are working here with Western speculative notions of "beauty".
} 
of analysis created by Glauber Rocha ${ }^{4}$, showing how second-hand materials discarded by the rest of the industrialized world ends up in developing countries, and the ways in which they are re-used, re-arranged, and re-signified.

Thirdly, the symbolic importance of these materials goes beyond their economic qualities. The making of masks, a long tradition in native African groups being lost today, is reinforced in "La bouche du roi". The reclaiming of Black African identity, in opposition to any cultural and economic domination from outside forces, is a demonstration of how contemporary African societies are trying to deal with current issues of exploitation and trying to reinvent themselves. Masks are still of great importance for African artists, as shown in this specific artwork, but the form of production has changed drastically, from the traditional mask to those of today. The materials of today's masks are the top parts of plastic containers, while the elaborately crafted and decorated masks from the past are being simplified today. These plastic masks still claim the magic remembrance of the ancestors and still cry for those loved ones who went away, showing that the traditions of the Yoruba, Igbo, and other cultures are still pulsing strongly in the hearts of African artists.

Fourthly, the direct relation to Thomas Clarkson's prints shows that this artwork seeks to reinterpret history, re-signifying the views about the slave trade and the economic mechanisms of modern world. As Picasso reinterpreted paintings such as Las meninas (Young ladies of the court) from Velásquez, Romuald Hazoumé, in a similar move, reinterprets Stowage of the British slave ship Brookes under the regulated slave trade 1789. Hazoumé's reinterpretation of the prints, into an installation, moves from paper and pencil to plastic containers, trying to reach a new understanding of the situation of the slave trade as something never to be forgotten, an ever-present memory.

This specific artwork references the "marks" left by the past (DIDI-HUBERMAN, 2008: p.155), those marks left on the sand beaches where these black people walked before being forced into slavery and transported to another continent. In the same way as the "marks left on the sand", "La bouche du roi" addresses the issues of the present, such as the exploitation of natural resources in Africa, where a very small percentage of the profit made by the oil industry is used to benefit the

\footnotetext{
4 We can not forget here the differences in political and economical situation related to Glauber Rocha's concept of the "aesthetics of hunger". Rocha worked during the military regime in Brazil and questioned some aspects of underdevelopment in Brazilian society. Our use of this concept relates mostly to the use of artistic materials, in the form of second-hand materials, found in developing countries and the significance of these materials for the understanding of the artwork examined, as well as of the economics of where it was created and relates to.
} 
local population. These plastic masks show a real significance in relation to the present economic circumstances in Africa.

In addition, those people, from the ancient Kingdom of Dahomey ${ }^{5}$ and many other African nations, who were taken as slaves and transported as animals to be sold in Brazil, the United States and the Caribbean, should always be remembered, and Hazoumé's installation fulfills this function as an object of memory. These free people, who would become slaves sold in markets, arrived in their "new" land to work in the cotton or sugar plantations, to serve inside the colonial houses, or to sell products for the benefit of their owners, among other forms of labor, should always be remembered in their ancestors' power. In this way, these masks reinforce the memory of our ancestors.

But the forced displacement of these people during colonial times has been replaced today by a different kind of displacement, one due to economic reasons. In the last three decades, the movement of the black population has shifted. The displacements of colonial times from Africa to the cotton or sugar plantations of the Americas as slaves, has today transformed into the movement of a cheap labor force into Europe and the USA. An example of this "new" form of displacement is that of Africans trying to sail into the Spanish Canary islands, dreaming of becoming immigrant workers in Europe.

If in the past the blacks were captured and transported across the sea to be sold as slaves, nowadays they continue to cross the ocean in an attempt to reach a new life in an economically rich nation. Regarding these new forms of displacement, Pauline de Souza informs us that the British black population refers to the current immigration movement of Africans and Caribbeans into Britain as a diaspora, causing them to create diasporic discourses that deal with past and current facts related to these displacements:

\footnotetext{
Diasporic discourses have encouraged black artists in Britain to develop a global consciousness over recent decades for two reasons: firstly the experience of economic interdependence between North America and Europe caused changes in world power and cultural consumption; secondly, within the shifts of late capitalism and global communications networks national or state boundaries no longer act as economic and cultural barriers as they did in the past. Freedom of movement and interaction has created a new symbolic order of time and space that provided a new framework for joint cultural experiences, redefining cultural relations of power (SOUZA, 2006, p. 363).
}

5 Current Republic of Bénin, West Africa. 
From the passage above we can see that the black British population reaffirms the need for understanding "La bouche du roi", as well as the need for the British Museum to own such a work. "La bouche du roi" defines the new ways in which the colonial past can be re-told, reunderstood, and thus serve as a tool of black empowerment.

Image 3 - Slaves selling their products, Rio de Janeiro (Brazil), 1860. Unknown photographers.

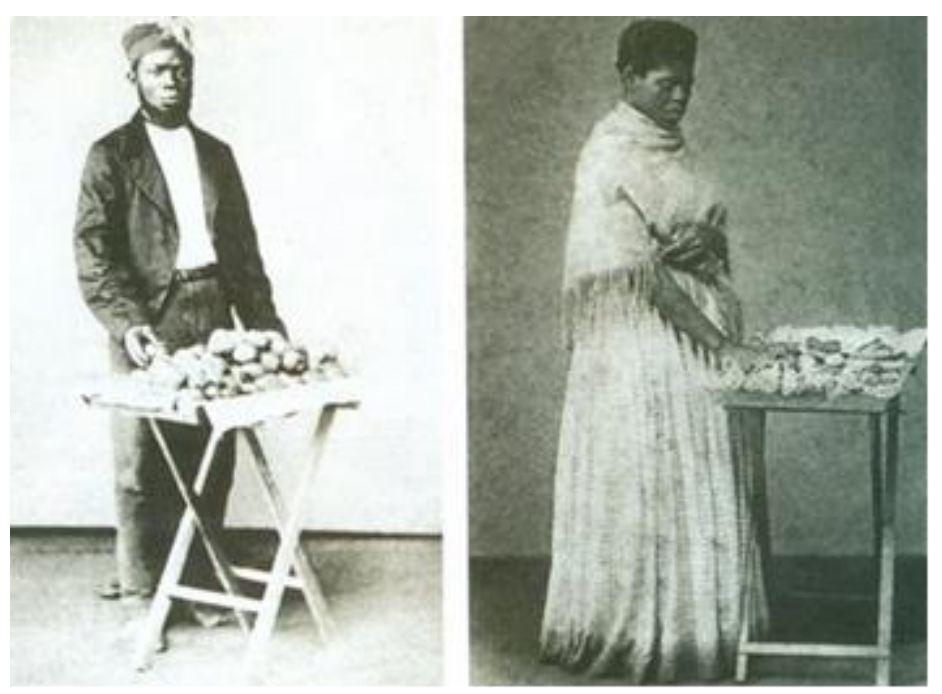

From: http://fabiosalvador.com.br/blogantigo/index.php?m=1043

A simplified definition for the term 'diaspora' could be "the dispersion of people from their original homeland." Whether in reference to colonial times or today, as afro-descendants leave the ex-colonies (nowadays independent countries) to look for a better life in Europe or the United States, diasporic discourses demonstrate their current importance as inclusive discourses. They help minorities to have a place in history, and become recognised as part of the social and cultural foundations of a contemporary nation.

The fifth and last point of our analysis is the way in which the name of the work is very suggestive. It imparts the image of the mouth of the king as being open, a mouth that could not "eat" enough from the black slave trade.

The name of the installation is also a real place in the Republic of Bénin, the estuary of the Mono River. Georges Bataille defines the mouth as the beginning of the body of the animal, and as 
having a possible violent meaning latent in mankind, which we could relate directly to the violence of the slave trade:

\begin{abstract}
Among civilized men, the mouth has even lost the relatively prominent character that it still has among primitive men. However, the violent meaning of the mouth is conserved in a latent state: it suddenly regains the upper hand with a literally cannibalistic expression such as mouth of fire, applied to the cannons men employ to kill each other. And on important occasions human life is still bestially concentrated in the mouth: fury makes men grind their teeth, terror and atrocious suffering transform the mouth into the organ of rending screams (BATAILLE, 1970, p. 21-22).
\end{abstract}

It is not precisely known how many blacks were transported as slaves from Africa to the Americas, but some researchers believe it was an immensely large number of people, a figure estimated to be in the millions. In Brazil, it is easy to conceptualize this large number, since a great part of the population is of black descent in the states of Rio de Janeiro, Bahia and Minas Gerais, the most economically important states during the colonial period in Brazil. The same can be said for the southern region of the United States or the islands of the Caribbean, such as Haiti or Cuba.

Image 4 - Woman with her two slaves in Bahia (Brazil), 1860. Unknown photographer. Property of Instituto Moreila Sales.

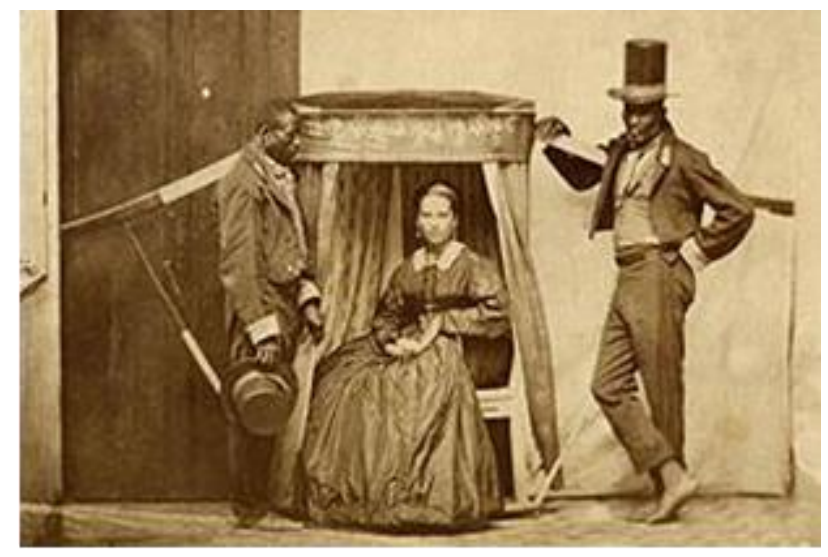

From: https://br.pinterest.com/pin/380061656036873252/

We believe that many other observations can be made about this specific work by Hazoumé, but, certainly, this work succeeds in collecting visual, cultural and material aspects that question the hegemony of European racial discourse during colonial times, as well as the current imperialist discourse of modern times. 
The site specific artwork "La bouche du roi" demonstrates an ethical responsibility concerning the conditions of the population in areas of oil exploitation. It makes powerful connections between the ways in which Africans were forced by European traders to leave their lands in the past, as well as the ways in which Africans and Afro-Americans6 still move or suffer due to economic reasons. It also shows how works of art can empower people, making them understand that they have the right to have opportunities, and that the so-called 'Western world' is obliged to include the issues of the black population in their discourse. The inclusion of the black population in this discourse must work against marginalization and be free of any sort of Christian charity, because the black population exists and deserves respect just like anyone else in the 'First World.'

Today, this respect for the cultural production of the 'Other' is starting to be noticed more and more as an ethical attitude, instead of as a charity. As a new world order starts to take shape, the hegemonic discourses produced in Europe and the United States have begun to decrease in importance. Other countries, such as Brazil, Russia, India, China, South Africa, and Mexico, among others, have started to seek more prominent roles for themselves and for other developing nations in the global setting. This shift, we believe, is very important for Africans and their cultural artifacts, as more visibility will be given to African and black artists, thus resulting in more African art being shown around the world. In this sense, "La bouche du roi" is an excellent example of such a change in views regarding art produced outside of the USA-Europe axis. We hope that this change can be truly seen and respected, but for now, we must continue to work towards the inclusion of minority groups in global discourses, no matter the context in which these discourses are produced.

\section{FINAL CONSIDERATIONS}

This paper has aimed to relate some reflections on contemporary African art, taking as an primary example the installation work by Romuald Hazoumé "La bouche du roi". This work of art has helped us raise some questions regarding the production of art in the developing world.

The deep ambivalence of all the materials used to compose this specific work of art demonstrates the exorbitant power given to industrialized products instead of people, all based on the plans of a slave trade ship from colonial times. 
We understand that the artwork of today never ceases to present multiple aspects of contemporary issues and their paradoxes. So, we should ask ourselves: what is this power that lies in the depths of a work of art produced in a developing country? Does it have an impenetrable surface? What secrets are concealed in its messages, if it does anything other than exhibit its presence and histories?

Also, we verified that the work "La bouche du roi" shows a highly politicized character and is engaged with the problems of the local population, highlighting the striking character of artistic manifestations made by non-Western artists who seek to reflect on identity and a past marked by oppression. On the other hand, the most common feature of the art produced in the USA-European axis is that it is more linked to the idea of expressive freedom and autonomy of the aesthetic field, which in post-modern times has led to less politically engaged works of art than works such as the African piece "La bouche du roi". We note, therefore, that there is a stronger need for historical, political, identity and social expressions of the artists outside of the hegemonic axis, than of those belonging to the USA-European axis.

One thing is clear: works of art produced in developing countries have the power to interrogate the public in a more groundless way, while at the same time interrogating and confronting history, and clearly questioning the privileged production of truths by the Western world.

\section{REFERÊNCIAS}

BATAILLE, Georges. Le Dictionnaire Critique. Orléans: L’Écarlate, 1970/1993.

BHABHA, Homi K. "Postmodernism/Postcolonialism”, In: NELSON, Robert S.; SHIFF, Richard (ed.), Critical terms for art history. Chicago: The University of Chicago Press, 2003, 2. ed, p. 435-451.

DIDI-HUBERMAN, Georges. Ante el tempo: historia del arte y anacronismo de las imágenes. Buenos Aires: Adriana Hidalgo editora, 2008.

GASKELL, Ivan. "Beauty", In: NELSON, Robert S.; SHIFF, Richard (ed.). Critical terms for art history. Chicago and London: The University of Chicago Press, 2003, p. 267-280.

SOUZA, Pauline de. "Implications of blackness in contemporary art", In: JONES, Amelia (ed.). A companion to contemporary art since 1945 . Oxford: 2006, p. 356-377. 